Florida International University FIU Digital Commons

\title{
Listening/Reading for Disremembered Voices: Additive Archival Representation and the Zong Massacre of 1781
}

Jorge E. Cartaya

Florida International University, jcart037@fiu.edu

DOI: $10.25148 /$ etd.FIDC001787

Follow this and additional works at: https://digitalcommons.fiu.edu/etd

Part of the Caribbean Languages and Societies Commons, Comparative Literature Commons, Continental Philosophy Commons, Cultural History Commons, French and Francophone Literature Commons, Literature in English, Anglophone outside British Isles and North America $\underline{\text { Commons, and the Race, Ethnicity and Post-Colonial Studies Commons }}$

\section{Recommended Citation}

Cartaya, Jorge E., "Listening/Reading for Disremembered Voices: Additive Archival Representation and the Zong Massacre of 1781" (2017). FIU Electronic Theses and Dissertations. 3187.

https://digitalcommons.fiu.edu/etd/3187 


\title{
FLORIDA INTERNATIONAL UNIVERSITY \\ Miami, Florida
}

\section{LISTENING/READING FOR DISREMEMBERED VOICES: ADDITIVE ARCHIVAL REPRESENTATION AND THE ZONG MASSACRE OF 1781}

\author{
A thesis submitted in partial fulfillment of the \\ requirements for the degree of \\ MASTER OF ARTS \\ in \\ ENGLISH \\ by \\ Jorge Enrique Cartaya
}


To: Dean Michael R. Heithaus

College of Arts, Sciences, and Education

This thesis, written by Jorge Enrique Cartaya, and entitled Listening/Reading for Disremembered Voices: Additive Archival Representation and the Zong Massacre of 1781 , having been approved in respect to style and intellectual content, is referred to you for judgment.

We have read this thesis and recommend that it be approved.

$\begin{array}{r}\hline \text { Nandini Dhar } \\ \hline \text { Martha Schoolman } \\ \hline \text { Ana Luszczynska, Co-Major Professor } \\ \hline \text { Heather Russell, Co-Major Professor }\end{array}$

Date of Defense: March 27, 2017

The thesis of Jorge Enrique Cartaya is approved.

Dean Michael R. Heithaus

College of Arts, Sciences and Education

Andrés G. Gil

Vice President for Research and Economic Development and Dean of the University Graduate School

Florida International University, 2017 


\section{DEDICATION}

For the one hundred and thirty-two or one hundred and fifty human beings kidnapped, enslaved, and jettisoned into the Atlantic, as well as to the two hundred and eight survivors of the ZONG's 107-day voyage across Middle Passage. We will never hear your voices or learn your names, but I strain to listen and bear witness all the same. This task is beyond my competence, yet it is your silenced voices that have exhorted me to undertake it. 


\section{ACKNOWLEDGMENTS}

Although this Yoruba proverb is repeated to the point of cliché, its meaning has resonated so keenly in my own lived experiences that I believe its significance has yet to be exhausted: It takes a village to raise a child. The village that extended itself toward me during my two years of graduate study is constituted by dozens of people both within and beyond the halls of this university. It is their kindnesses, big and small, that have nourished me throughout the writing of this thesis. I am here due in large part to them, and I am thoroughly indebted to each of them for seeing me this far.

My parents, Rebeca Garcia-Cartaya and Jorge Cartaya, have supported me emotionally, intellectually, and financially throughout my life. As I recovered from an illness in 2014 , they encouraged me to pursue my M.A. sooner rather than later, and it is thanks to their support that I stand here now. Along with them, I must acknowledge and thank the other members of my family, both by blood and choice, who made me possible: Lourdes, Rosaura, and Elio Garcia; Margarita, Gisele, and Yesenia Del Busto; Sara and Carmen Cartaya; Catherine and Ramon Magarino; Alma Martinez-Amores; and Junting Huang. Thank you.

The staffs at the Starbucks Coffee on Coral Way $\& 87^{\text {th }}$ Ave and 107 Coffee and Dessert have kept me well-fed and well-caffeinated through the many a deadline. You have my gratitude for your warmth and regular offering of a table or booth for me to read, write, and think.

To my professors, mentors, and committee members, Ana Luszczynska, Heather Russell, Martha Schoolman, and Nandini Dhar: your belief, generosity, and steadying support have not only buoyed and validated me through numerous moments of 
uncertainty, but also disclosed entire worlds for me to inhabit and pursue. To say that the opportunity to meet, study under, and work with each of you was life-changing would be an understatement. It is my sincere hope that this thesis amounts to at least a portion of the efforts you have put into mentoring me. Along with them, I owe my gratitude to Professors Asher Milbauer, Maneck Daruwala, Michael Patrick Gillespie, Jason Pearl, Donna (Aza) Weir-Soley, Cindy Chinelly, and Kimberly Harrison, as well as to Natasha Neckles and Gretter Machin — it is thanks to all of them that I made it into, through, and beyond this wonderful M.A. program. You each have stimulated my growth and enriched my being. Thank you.

My cohort, peers, and dear friends were the cornerstones for my quality of life and growth. I do not have the words to express my gratitude toward Gabby Benavente, Junting Huang, Autumn Hyatt, Catherine Zaw, Roxanne Mayrand, Amanda Aragon, Raquel Vallecillo, Laura Aguirre, Shivani Chandra, Anne Nguyen, Jordan Gilchrist, Stephanie Selander, Irene Inatty, David Frisch, Allison Sardinas, Lauren Romaguera, Zina Hutton, and Marlene Tovar for their friendship, commiseration, camaraderie, andmost of all—for the joy and nourishment they bring to my life daily.

As I prepare to transition to a to-be-determined Ph.D. program in the fall, I move forward only because you showed me how. I will remember each of you. 


\title{
ABSTRACT OF THE THESIS \\ LISTENING/READING FOR DISREMEMBERED VOICES: ADDITIVE ARCHIVAL REPRESENTATION AND THE ZONG MASSACRE OF 1781
}

\author{
by \\ Jorge Enrique Cartaya \\ Florida International University, 2017 \\ Miami, Florida \\ Ana Luszczynska, Co-Major Professor \\ Heather Russell, Co-Major Professor
}

This thesis grapples with questions surrounding representation, mourning, and responsibility in relation to two literary representations of the ZONG massacre of 1781 . These texts are M. NourbeSe Philip's ZONG! and Fred D'Aguiar's FEEDING THE GHOSTS. The only extant archival document - a record of the insurance dispute which ensued as a consequence of the massacre-does not represent the drowned as victims, nor can it represent the magnitude of the atrocity. As such, this thesis posits that the archival gaps or silences from which the captives' voices are missing become spaces of possibility for additive representation. This thesis also examines the role voice and sound play in these literary texts and the deconstructive-ethical philosophies of Jean-Luc Nancy and Jacques Derrida. This thesis argues that these texts invoke the sonic materiality of voice in the service of responding to the disremembered dead through mourning and acknowledgment. 


\section{TABLE OF CONTENTS}

Introduction:

Listening/Reading for Disremembered Voices: Additive Archival Representation

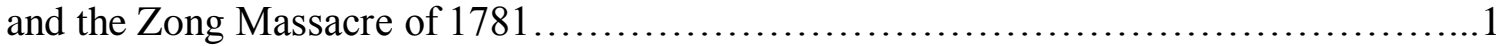

Section 1:

Figured Voices: The Call to Responsibility

Section 2:

In the Interim: Black Noise and Manufactured Archival Silence. ...

Section 3:

Material Responses: Voice, Song, and Pure Utterance....

Conclusion:

Living in the Afterlife of Slavery.

Bibliography. .57 


\section{Introduction:}

Listening/Reading for Disremembered Voices: Additive Archival Representation and the

\section{Zong Massacre of 1781}

So here is what we believe we know at least, here is the appearance: the other will never again respond. Now in spite of these necessities, these obvious facts and these substantiated certitudes, in spite of all the reassuring assurances which such a knowing or such a believing-to-know dispenses to us, through them, the phantom continues to speak. Perhaps he does not respond, but he speaks. A phantom speaks. What does this mean?

- Jacques Derrida, Archive Fever

Not unlike Derrida's Archive Fever, my project begins not at the archive, but rather at the phantoms of drowned captives that speak in and through silence, their voices circumscribed by a dearth of archival records.

On 6 September 1781, the slave ship Zong departed São Tomé and set a course for Jamaica. Below deck, 470 kidnapped Africans were crammed into a cargo hold designed to hold less than half their number. The crew numbered at 17 , too small to maintain adequate sanitary conditions aboard the ship. Six to nine weeks was the customary duration of such a venture, but - as a result of a navigational error on the part of its Captain Luke Collingwood - it would be 107 days before the ship would arrive at its destination.

When the Zong finally arrived at Black River, Jamaica on 22 December 1781, there were only 208 Africans in the cargo hold. These survivors were subsequently sold at market. The disappeared 262 persons were deemed lost cargo: "sixty negroes died for want of water for sustenance; and forty others, for want of water for sustenance, and through thirst and frenzy thereby occasioned, threw themselves into the sea and were 
drowned; and the master and mariners, for the preservation of their own lives and the lives of the rest of the negroes... were obliged to throw overboard 150 other negroes" (qtd. in Philip 210).

These quantitative figures are well-documented, but if we were to search for the names of those who were murdered aboard the Zong, we would not find them. The drowned are not named in the slave ship captain's ledger, the auctioneer's bills of sale, the slaveholder's account books, nor do they appear in the court stenographer's transcript of the insurance dispute that ensued as a consequence. With respect to the Zong's 107day voyage and its crew's decision to throw 150 Africans overboard to their deaths, few records remain. The ship's logbook is thought to have disappeared along with its Captain Collingwood when he disembarked in Jamaica on 22 December 1781. What remains is the legal paraphernalia of insurance dispute, Gregson v. Gilbert.

None of the surviving documents name the drowned, nor do they preserve their voices.

Perhaps the closest we can get to their names is the sales book of Thomas Case, an agent in Jamaica who did business with the Gregson syndicate, owners of the Zong. In "Notanda," the epilogue to her collection of found poetry, M. NourbeSe Philip recounts her experience reading a copy of Case's sales book, which she received from a colleague. Although the document does not account for the transaction in which the survivors from the Zong were sold, NourbeSe claims, "It is typical of records kept at that time: Purchasers are identified while Africans are reduced to the stark description of 'negroe man,' [sic] 'negroe woman,' or, more frequently, 'ditto man,' 'ditto woman'” (Philip 194). What do we know apart from that? "Their financial value... was recorded and 
preserved for insurance purposes," NourbeSe notes (194). As such, we know that the survivors were valued at 30 pounds sterling a head.

Apart from that? Nothing but one more, meagre detail. It is the word itself. "Meagre" is the word Case used to describe enslaved girls. As such: "Negroe girl (meagre)." "There are many 'meagre' girls," NourbeSe writes, "no 'meagre' boys" (194). Beyond that single word, nothing more.

For those who read the colonial and slavery archives in search of the enslaved's names and voices, "meagre" is perhaps the best adjective to describe the records themselves. Those words constitute the meagre sum of what these archives can offer us about those murdered aboard the Zong. Archival records simultaneously circumscribe the enslaved in the impossibility to know anything particularizing about them, yet also constitute the horizon of possibility for our ever learning about them. In other words, it is because the slave ship captains, auctioneers, masters, and courts recorded their transactions so fastidiously that we know that this massacre happened at all. The enslaved's phantoms speak in and as archival silence.

Confrontations with this and other archives of slavery and colonization have marked a site of literary plenitude in recent years. By acknowledging that the archives do not represent the enslaved and colonized Other as persons, these literary interventions often function as what Martinican philosopher Édouard Glissant calls a tale, which "can react to a gap in history by simply acknowledging it" (Glissant 84) and queer theorist Anjali Arondekar terms an "additive model of subalternity," or "the desire to add and fill in the gaps with voices of other unvoiced subalterns" (Arondekar 6), and Saidiya Hartman names "the instant of possibility" ("Venus in Two Acts" 8). As narrative, 
additive representation often functions by centering points of view forbidden from the archival record. For instance: there are no extant autobiographical narratives by female survivors of the Middle Passage, let alone survivors of the Zong. As such, a novel like Fred D'Aguiar's Feeding the Ghosts (1999) — by including the first-person testimonial of Mintah, D'Aguiar's invented female survivor of the Zong massacre-responds to the archival dearth. In the Glissantian mode, D'Aguiar's text "attacks the sacred status of the written word" of History in Gregson v. Gilbert by exploiting the legal text's omissions (Glissant 84). Rather, the information recorded in Gregson v. Gilbert does not and cannot preclude the possibility that, unbeknownst to the archivist or unacknowledged by the archival record, a captive like Mintah may have survived being thrown overboard. In this sense, additive representation exposes the fallibilities of History, which is itself a representative master narrative fashioned from the testimonials of witnesses who were said to have been present at the event in question. The silences in archival history allow cultural producers to fill its gaps with tales and voices that, although fabulated ${ }^{1}$, remain possible. As such, additive texts themselves read as archives of possibility.

However, these literary-archival interventions have also emblemized a problem of additive representation. That is, how and why does the archive limit additive interventions? In "Venus in Two Acts," Hartman explains, "The archive of slavery rests

\footnotetext{
${ }^{1}$ In "Venus in Two Acts," Hartman describes a writing practice she names "critical fabulation." She writes, "This double gesture can be described as straining against the limits of the archive to write a cultural history of the captive, and, at the same time, enacting the impossibility of representing the lives of the captives precisely through the process of narration" ("Venus in Two Acts" 11). She goes on, "Narrative restraint, the refusal to fill in the gaps and provide closure, is a requirement of this method, as is the imperative to respect black noise - the shrieks, the moans, the nonsense, and the opacity, which are always in excess of legibility and of the law and which hint at and embody aspirations that are wildly utopian, derelict to capitalism, and antithetical to its attendant discourse of Man" (12).
} 
upon a founding violence. This violence determines, regulates and organizes the kinds of statements that can be made about slavery" ("Venus in Two Acts" 10). Founding violence circumscribes possibility. Although extant archival records deny the dead their names and voices, they also catalogue the statements that licensed their deaths aboard the slave ship (10). To remain possible, each tale must not trespass the limits of the archival record. We cannot undo the archive's founding violence: it is impossible to recover the dead's names or to restore their lives. Therefore, in attempting to excavate possibility for the enslaved through narrative, one must not fail to account for the material incumbencies that defined their lives and their deaths.

At the same time, each tale's narrative must remain singular - that is, one possible tale among a multiplicity of other possibilities. Our inability to know what happened aboard the Zong, which is itself the condition of possibility for every singular tale, also makes it impossible to determine which tale is most accurate, factual, or true. Additive representation can only function as an archive of possibility insofar as it problematizes any attempt to create a single master narrative, including an attempt of its own.

For instance, in "The Dead Book," the seventh chapter of Lose Your Mother: A Journey Along the Atlantic Slave Route, Hartman tells six tales. All six focus on the torture and murder of a girl aboard the slave ship Recovery in 1791. Each tale, Hartman explains one year after publishing Lose Your Mother, was intended "to expose and exploit the incommensurability between the experience of the enslaved and the fictions of history" ("Venus in Two Acts" 10). The first five tales are narrated from the perspectives of Captain John Kimber, the girl's murderer; the Recovery's third mate and surgeon, who 
witnessed her torture and murder; William Wilberforce, the English abolitionist who successfully lobbied Parliament to try Kimber for the girl's murder; and John Weskett, who wrote an eighteenth century tome on English insurance law.

The sixth and final tale, however, is what I would like to focus on more closely. My reason for emphasizing the sixth over the others is that, unlike the previous five tales, this tale is told from the girl's perspective. Although Hartman alters nothing insofar as the girl is still starved, tortured, and murdered in her tale, she still breathes an instant of possibility into the narrative by affording the girl a measure of resistant hope: as she dies, the girl does not think of herself as a "pitiful and weak...girl slumped in a dirty puddle"; instead, she imagines her death as "a way off the ship" that would send her "soaring and on her way home" (Lose Your Mother 152). Those six words-soaring and on her way home - conclude the girl's tale. Immediately afterward, however, Hartman confesses to a lingering malaise.

If the story ended there, I could feel a small measure of comfort. I could hold on to this instant of possibility. I could find a salutary lesson in the girl's suffering and pretend a story was enough to save her from oblivion. I could sigh with relief and say, 'It all happened so long ago.' Then I could wade into the Atlantic and not think of the dead book. (153).

Here, Hartman issues a warning: despite the possibility that the girl's tale may succeed in exposing "the incommensurability between the experience of the enslaved and the fictions of history," it is not enough to "save her from oblivion" "Venus in Two Acts" 10). Hartman's recognition that "[her] account replicates the very order of violence that it writes against by placing yet another demand upon the girl, by requiring that her life be made useful or instructive, by finding in it a lesson for our future or a hope for history" both haunts and sobers her (14). She knew it from the beginning, by her own admission, 
and yet - even so, she cannot allow herself to "sigh with relief" and distance herself from the girl's murder, much less the other histories of the Middle Passage; nor does she stop herself from disinterring other instants of possibility a year later in "Venus in Two Acts," always with the cognizance that the "task of writing the impossible...has as its prerequisites the embrace of likely failure and the readiness to accept the ongoing, unfinished and provisional character of this effort, particularly when the arrangements of power occlude the very object that we desire to rescue" (14). Fully cognizant that the task is an endless one, Hartman reaffirms that we can only continue trying to write the impossible, unrepresentable histories of the Middle Passage.

In other words, if the intent in additive representation lies in, as Hartman claims, "laboring to paint as full a picture of the lives of the captives as possible" (11), then it follows that each of these singular tales must engage something akin to a phenomenology of the slave ship. To depict the captive as an actor rather than an object, writers question how the enslaved related to or interacted with the material incumbencies documented by the archive. In other words, this questioning involves doing the work of depicting the enslaved as the persons they were. That is, as speaking, listening, feeling, tasting, seeing singular subjects possessing intentionality, structures of consciousness, and subjectivity.

Of these, our study aims to examine, most specifically, the phenomena of speaking and listening vis-à-vis both the historical event and additive textual representations of the Zong massacre. Or, simply put, the Zong as soundscape. More broadly, our study seeks to demonstrate how the figure of the singular voice responds to several of the dilemmas surrounding the question of additive representation. What does it mean for a phantom to speak? Moreover, what does it mean for a phantom to speak in, as, 
and through silence? Is it possible to create a textual space in which a voice may resurface?

By reading the texts of M. NourbeSe Philip, Fred D'Aguiar, Jean-Luc Nancy, Jacques Derrida, and Toni Morrison for the voice, I will demonstrate that — as sonic phenomenon - the voice is a site in which historical materialist and deconstructive-ethical approaches to the Middle Passage intersect and enrich one another. Instead of plumbing the enslaved's voice for discursively meaningful content, I prioritize the co-constitutive material and ethical dimensions of the voice as sound. The intention informing this project is nothing as revelatory as explaining how creative writers - be they NourbeSe, D'Aguiar, or Morrison - recover the voices of the murdered slaves, but rather to examine how they apprehend the form which creates the space in which these singular voices may sound out and, possibly, be heard.

Like the living, the dead had their own voices. The question then becomes how we can access, carry, bear witness, or listen to voices that have, long before our births, been forever lost. In acknowledgment of this question, voice is examined in two distinct, yet closely interrelated dimension: first, the figured or represented voice; second, the irrecuperable singular voice as material sound. Whereas the first of these dimensions refers to the absence of the captives' perspective or voice from the archival record, the second underscores the literal voice of the captive, lost with their death. In the absence of the dead captives' voices as such, additive representation recreates or figures possible voices. While these possible voices and the enslaved's singular voices are incommensurate, I will demonstrate how their inaccessibility and incommensurability safeguards and enables each. The absence of the singular, material voice is not nothing. 
Rather, it is the palpability of its absence from the archival record as silence that both enables and demands additive representation. In this sense, many of the "rhetorical" dimensions of voice, as outlined in the first section on Nancy and Derrida, belong most properly to the material dimension of voice as sound. 


\section{Section 1:}

The Figured Voices: The Call to Responsibility

Must we bear witness to the nameless and disremembered dead who perished aboard the Zong? If it is indeed impossible to undo the founding violence of the archive by representing their material, singular voices as such, then why create additive representations of their figured voices in the first place?

This dilemma stems from a particular confusion surrounding the in/adequacy of representation. The absence of the captives' figured voices from the archive is what necessitates the creation of supplementary, literary archives of possibility, but it is also the loss of their material voices - which is to say, not solely their voices, but also their singular subjectivities — with their deaths which imbues the work of additive representation with the urgency of an imperative. Without their voices as such, there are only possibilities and material incumbencies. In other words, the lack of the captives' voices and our inability to recover them as such prohibit definitive narrativization or knowledge of the event in question, as with historical accounts. This prohibition also extends to narratives that omit the captives' voices, because silence and omission in historical narratives are themselves forms of foreclosure to possibility.

Whether explicitly thematized as such or not, the question, which I will call the question of the imperative, nonetheless preoccupies not only Hartman's projects, but the projects of her contemporaries. Poet M. NourbeSe Philip, for example, acknowledges that, while writing Zong! - a collection of found poetry through which she attempts to bear witness to and represent the Zong massacre of 1781—she risks becoming like Luke Collingwood, the Zong's captain. Or, as Victoria Austen frames NourbeSe's dilemma in 
her article “Zong!'s 'Should we?': Questioning the Ethical Representation of Trauma," "If [NourbeSe] assumes the power to represent the massacre without remaining conscious of her questionable right to do so, her act of representation could like-wise be a form of domination" (Austen 66). Even so, NourbeSe affirms, and reaffirms, her obligation to write Zong!. She writes, "This story that must be told; that can only be told by not telling [emphasis added]" (qtd. in Saunders 74). NourbeSe's apprehension of becoming Collingwood, we will note, resonates keenly with Hartman's sobering acknowledgment that, in attempting to represent the experiences of the two girls murdered aboard the Recovery, she has replicated the violence that allowed the girls to be murdered in the first place. Similarly, NourbeSe's commitment to tell the story of the Zong massacre's victims by not telling foregrounds Hartman's affirmation that the task of writing the impossible must embrace its likely failure. To tell without telling, then, is perhaps to embrace the impossibility of representation, which, as we have seen, constitutes the very horizon of possibility for telling.

Like Hartman and NourbeSe, Omise'eke Natasha Tinsley grapples with the question of the imperative in her article "Black Atlantic, Queer Atlantic: Queer Imaginings of the Middle Passage." With Tinsley, the question manifests in her concomitant insistence that we acknowledge the material lived experiences that give the oceanic metaphors of the black Atlantic their power and refusal to figure the Atlantic as a point of origin for blackness, queerness, or black queerness. Indeed, while Tinsley takes theorists like Paul Gilroy and Antonio Benítez-Rojo to task for "[mining] the metaphoric possibilities of the sea" (Tinsley 195) without "[plumbing] the archival ocean materially, as space that churns with physical remnants, dis(re)membered bodies of the Middle 
Passage" (194), she also refuses to "strip theory of watery metaphors" (212) altogether. Tinsley also critiques Gilroy, Benítez-Rojo, and Glissant for overlooking the queer experiences and histories of the Middle Passage; in this vein, her thinking resonates with Hartman's exposition of the exigency "to paint as full a picture of the lives of the captives as possible" ("Venus in Two Acts" 11). Tinsley goes on to write, "The maritime metaphors of Gilroy and Benítez-Rojo move toward a kind of closure.... Yet such closure is made possible only by washing over important materialities and multiplicities in visions of diaspora and region" ("Black Atlantic, Queer Atlantic" 202). By "washing over important materialities and multiplicities," Tinsley claims, Gilroy’s and Benítez-Rojo's metaphors move toward closure, toward an end - a closure and an end of metaphor that, as we have observed, is impossible by its very condition of possibility. For Tinsley, then, the question of the imperative presences in "Black Atlantic, Queer Atlantic" as the exigency to acknowledge the unknowable lived experiences of the enslaved Africans that nonetheless imbue metaphors with their power. Moreover, and perhaps most strikingly, Tinsley—like Hartman and NourbeSe—responds to the question with her intervention.

As we have observed, Hartman, NourbeSe, and Tinsley each grapple with—and respond to - the question of the imperative within the histories of enslavement and postcolonial theory. However-and although my own project, like Hartman's, NourbeSe's, and Tinsley's, is most precisely interested in disinterring the enduring imperatives of the Middle Passage — the histories of enslavement and postcoloniality are not the only contexts within which one may disinter these exigencies, these instants of possibility. I would submit that the question of the imperative, the same endless task, 
inexorably demands the attentions of Jean-Luc Nancy and Jacques Derrida as well-if in a different, yet still identifiable, form.

In his essay "The Free Voice of Man,” Nancy thematizes this imperative to remain open to possibility by linking it with the structure of a question. He writes, "The obligation is, more simply, more modestly, one of maintaining (garder) the question, as a question" (Lacoue Labarthe and Nancy 39). To maintain the question as a question, the imperative to possibility must interrupt any force that threatens to deactivate the question. As James Gilbert-Walsh describes the imperative in "Broken imperatives: The ethical dimension of Nancy's thought," "Being-in-common happens as a kind of interruptive 'event', an event which is not merely a condition for the possibility of concrete communication but this very communication itself" (Gilbert-Walsh 31). Gilbert-Walsh goes on to write, "This interruptive event whereby being-in-common 'happens' is none other than the imperative address par excellence-but such that the sens of the imperative must be heard otherwise, and heard otherwise each time it is heard" (31). Being-incommon, which for Nancy is a constitutive event of being wherein my and the other's finitude $^{2}$ is co-exposed, occurs most properly as a singular interruption. We will note that being-in-common, finitude, and interruption each refer to specific articulations of the same constitutive event of being ${ }^{3}$, and that it is as, in, and through this movement - a

\footnotetext{
${ }^{2}$ In Martin Heidegger's Being and Time, finitude, or being-towards-death, refers to the recognition that we as human beings will one day die and thus have a finite amount of time with which to live. Nancy expands on Heidegger's notion of finitude by observing that we recognize our finitude through a co-exposure: by witnessing the death of another, I recognize that one day I will die as well. So too is the case for the other, who recognizes their finitude through my own death.

${ }^{3}$ In her reading of Nancy's “The Inoperative Community," Ana Luszczynska notes, "The terms ecstasy, singularity, and community are so closely related that one could argue that they are indistinguishable" (56).
} 
preconscious and prelinguistic constitutive event of being - that the imperative address is heard.

While the imperative to possibility speaks as, in, and through a constitutive event of being, it is also singular. In the words of Gilbert-Walsh, the imperative must be "heard otherwise each time it is heard." The sharing, dividing, and co-exposing of finitudewhich Nancy also refers to as community, his reformulation of Heideggerian being-with [Mitsein] as first philosophy—may only happen with the other. But we know that "the other" is a collective noun; it refers not to one other par excellence, but to all possible others. Our being-with is a being-many, and it this being-many that makes the imperative address singular. Each time I encounter an other, which is to say each time I encounter a- possibly but not always necessarily different (that is, not only different from me - and difference from me is what makes the other other to me and makes me other to the other-but different from other others, which is the difference that makes each other singular) - other, I must listen to the imperative address otherwise. That is to say, difference is implicated here not only between others, but also between encounters with others. Although I may encounter the same other multiple times, the experience of each encounter will necessarily differ from all previous and future experiences of encounter with that particular other. As such, the imperative address will not sound the same way each time, but will differ infinitely in each encounter with each other I am exposed to. So the imperative speaks, if it can be said to speak, as the singular voice of the other-all others to whom I am exposed, in each interruptive instant of that exposure.

We have disinterred a few crucial implications that require unpacking. First, that finitude compears. In other words, and to expand on my passing reference to this effect 
above: finitude is not; rather, finitude happens as an event—namely, an event with the structure of a co-exposing, dividing, and sharing with the other that is heard as the other's voice. The compearance of my and the other's finitude is the recognition that the other and I are finite beings: that we will die. Only the other can expose me to this recognition; after all, I cannot access my death myself until the instant of my death—at which point I have already died. By presenting me with my ownmost, radically irrecuperable death, the other gives me access to what-according to Nancy—is most properly my own. I therefore stand before the other already hopelessly indebted. It is in this way that my exposure to the other and the other's exposure to me interrupt any presumption either of us may have of being anything other than finite, singular beings. In "The Inoperative Community," Nancy frames the interruption this way: "Community is, in a sense, resistance itself: namely, resistance to immanence" (Nancy 35). Community, which is the compearance of finitude, intrinsically resists and interrupts immanence. Finitude (co)exposes what is at stake for us as singular beings. Because it is only through the other that I can be exposed to our finitude, I am as such responsible to the other. And because, at bottom, the other is other to me because they are different than me, it is "difference [that] brings forth duty by itself" (Lacoue-Labarthe and Nancy 46).

It is because we are finite, singular beings that the imperative speaks as and through the other's interruptive voice, or that we can conceive any notion of the ethical whatsoever. The voice speaks the opening of ethics, which obligates us to interrupt anything that would circumscribe the question of the imperative - for it is the question, by virtue of its very structure as a question, that can remain open to the other in a manner that the answer, by virtue of its very structure as a definitive answer, cannot. It is crucial 
here to draw a distinction between an answer and a response. Whereas an answer is definitive, a response is singular. In other words, an answer deactivates the question by answering it, as in a basic math problem; a response simply responds to the question without precluding other, different responses. Within the framework of additive archival representation, History is the answer and a tale, instant of possibility, or additive representation is a response.

Furthermore, Nancy asserts that community is a preconscious and prelinguistic constitutive event of being. If community is preconscious and prelinguistic, then we can never lose it - at least not until the moment of our deaths. As such, what follows the recognition of our inability to lose community is the recognition, closely related to the first, that we have never not been in and as community. That is, the other not only gives me the knowledge of my birth and my death, but the very language by which I am constituted. In predating language, that which constitutes my consciousness, community - being-with the other-resists any teleological attempt to trace it to a point of origin, which is itself a deactivation of the question that the imperative calls us to maintain. Nancy observes, "Community means, consequently, that there is no singular being without another singular being, and that there is, therefore, what might be called, in a rather inappropriate idiom, an originary or ontological 'sociality' that in its principle extends far beyond the simple theme of man as a social being" (Nancy 28). The groundless ground of being is what philosopher David Wood calls the "always already," or the recognition "that the origin is structurally recessive, that it cannot be represented within the conceptual level at which its absence is nonetheless being felt" (Wood 1-2). This is why, as Wood goes on to claim later in The Step Back: Ethics and Politics after 
Deconstruction, that "we think of responsibility too late if we think of it as a property of a 'subject'" (146). Indeed, as radically relational beings, we have always already been with the other, always already been indebted to the other, and always already been called into responsibility by the imperative. At bottom, and whether or not we choose to open ourselves to, acknowledge, or listen to their call, we are always already called into responsibility to the other.

As we have discussed, the imperative is closely related to the other precisely because it speaks as the interruptive voice of the other, which resists immanence and calls us into responsibility. That said, we have yet to ask: responsibility to whom? Why, responsibility to the other, of course. At this point, I will now shift to focus our thinking primarily on the question, imperative, and responsibility in Derrida and Wood.

In "Eating Well," Derrida says that "responsibility is excessive or it is not a responsibility [emphasis mine]" (qtd. in Wood 140). Apropos of this statement in Derrida, philosopher David Wood writes:

Derrida contrasts responsibility as calculable with responsibility as excessive. The way he elaborates on the excessive (references to the billions of my fellows, etc.) suggests an ill-advised quantitative interpretation, one that nonetheless rightly explodes any deal by which I have given myself a good conscience.... But there are two better ways of thinking of the interpretation of responsibility as openness to the other. The first I have already adumbrated: My exposure to the other means that there are no a priori limits to my responsibilities. But there are limits; I cannot save all the drowning children. The second way of grasping the interconnectedness of these two levels is no less significant here for having a broader application. Responsibility as openness to the other can function adverbially as a modal operator in the way we deal with and understand such finite responsibilities as we do take on: willingly accepting consequential or corollary responsibilities, and acknowledging responsibilities we would never have chosen. (147) 
Of course, Wood is correct to distinguish between exposure to the other as "some huge, excessive obligation" and exposure to the other rather as "a complex openness to requests, demands, pleas that call not just for an acknowledgment of my obligations, but for scrutiny, for negotiations, for interpretations, and, ultimately, for recognizing both opportunities and limitations" (146). Openness to the other does not translate simply and redoubtably into a willingness to shoulder and discharge a responsibility for them - that is, to act on an alleged responsibility on the other's behalf. To take on and discharge some perceived, ostensible responsibility for the other is not inherently ethical, but potentially and dangerously unethical. Indeed: what of the other to whom my intervention - my assumption of responsibility for them—is unwanted? And what of the Other for whom the conqueror, the colonizer, and the imperialist claimed responsibility, a white man's burden? We must not forget that the language of responsibility has been and continues to be used to justify colonization, enslavement, exploitation, and oppression. But by emphasizing that exposure to the other is instead a complex openness to requests, demands, and pleas, Wood underscores the imperative of hearing, listening, and responding to the other's call, the other's voice.

However, I hesitate to agree with Wood's misgivings about Derrida's elaboration on excessive responsibility. ${ }^{4}$ The adjective "excessive" describes the task of responsibility itself. In other words, it is not that we as finite human beings are inadequate before the task, but the task itself prohibits an end. Rather, I would submit that exposure to the other must not be delimited at the face-to-face encounter- but rather, and

\footnotetext{
${ }^{4}$ This intervention is based solely on my readings of this text, Wood's The Step Back: Ethics and Politics after Deconstruction, and his earlier book, Thinking after Heidegger.
} 
as Wood suggests with his emphasis on requests, demands, and pleas, that exposure also be considered in terms of the aural and the auditory.

My suggestion has a few dimensions. A voice is simultaneously singularsingularly of a single, unique singular being — and intrinsically toward, indelibly communicative. A voice spaces itself out from the singular being to whom it belongs and into the world. As such, there is never not a possibility that this voice may be heard by others. Moreover, there is never not a possibility that one may hear an other's voice in such a way that it would seem, in the moment of hearing it, disembodied. For instance, while walking down the street I may hear an other's voice coming from the next street over, an apartment with an open window, or a nearby car radio. In that moment, I may not be able to locate the other to whom this voice belongs. It does not follow than an exposure to the other's voice must coincide with a face-to-face encounter with the other themself. My exposure to the other's voice may occur in the form of a non-encounter, a non-coincidence. The first dimension of the suggestion, then, is that my exposure to the other need not occur in the same physical space.

Following inextricably in the wake of the first dimension, the second is that my exposure to the other need not occur in the same temporal horizon. One of the most accessible points of departure for this thinking involves the question of writing. Or rather: is the other's voice delimited to a verbalization? Can the other's voice be read as an inscription as well as heard as a verbalization? We will note that writing already ruptures the delimitation of exposure to the other as a face-to-face encounter. By inscribing my thoughts on a sheet of paper, for instance, I distance it from myself. The other can thus read my writing — hear my voice — even when I am not there with them. The act of 
inscribing, according to Barbara Johnson, transforms one's thoughts "into something that can be read by someone far away, even after the writer's death" (Johnson ix). With inscription, the spatial act of distancing one's thoughts from oneself through writing or audio recording constitutes a temporal dimension — an indeterminate time (indeed, at any time) after the writer's or speaker's death. Together, the spatial and temporal dimensions arealize the horizon of possibility for exposure to the other. According to Nancy, an areality is an event's "nature as an area, as formed space" (Nancy 20). Our use of this term places particular emphasis on the second of Nancy's gestures above; that is, to underscore these spatial and temporal dimensions as space-forming in an ontological sense. In these contexts, does my voice not sound out when I am not present- even, possibly, after I have died?

Yet we must take this thinking of exposure and its arealizing dimensions further. What of the dead other who was never privileged with the opportunity or skills necessary to inscribe and distance their thoughts from themself? What of the dead other who we only know as the Other - the slaves, the murdered, the drowned, the victims - and not by their names? What of the dead Other who we only know about through representations created by the Subject - the very same Subject that refused to represent the dead Other as anything but cargo, chattel, commodity, or property?

I am referring, of course, to those enslaved aboard Zong. At nearly every turn, the voices of the enslaved Africans have been silenced and forbidden from the preservation of the colonialists' and slavers' archives. Yet, as NourbeSe reminds us, "their archivethe archive of the owner and the lawmaker-is in fact the only [grave] marker" for the drowned Africans (Saunders 69). As we have observed, these archives are the horizon of 
possibility for our knowing about the dead we will never be capable of naming or listening to as such. How, then, can we be exposed to this enslaved other-these millions of others denied their names and their voices? Can we be responsible to the other whose voice we can only know as silence?

But the absence of something is not nothing 5 , and it is precisely this "not nothing" that we must attempt to tease out. In other words, my exposure to the other as such: not simply to the other with whom I share a spatial and temporal horizon- the other with whom I am there with (which is to say physically present alongside) at the same time and in the same place — but to the other to whom I am exposed only through a representation. In other words, both archival silence and additive archival representation expose us to the lost voices of the enslaved precisely as an absence. And, in this vein, I would push the limit yet further: I am in some way responsible to the other to whom I can only ever be exposed through representation; to the other for whom it is impossible to encounter me, separated as we are by time, space, and death?

Again: must we bear witness to the nameless and disremembered dead who perished aboard the Zong? What does it mean that their phantoms speak in silence?

Their voices, as a silenced absence and additive representations, respond: yes, we must. Bearing witness through the addition and guarding of possibility itself responds to

\footnotetext{
${ }^{5}$ In her insightful explication of Nancy's "The Inoperative Community," Ana Luszczynska links the notion of the "not nothing" to a thinking of excess and sovereignty. She writes, "...the excess to which being is exposed and abandoned (which is sovereignty) is not a substance. It is not a thing that could present itself or let itself be appropriated. In fact, Nancy indicates that this excess, properly speaking, is not, in a manner similar to the way that Heideggerian Being is not" (Luszczynska 59). In this context, a thing or substance is best conceptualized as a form that is static or congealed enough to present itself visibly. On the other hand, sound is no-thing; that is, it is not a thing, but rather occurs as a material phenomenon or event. Yet despite the fact that sound is not a substance, that does not mean that it is nothing.;
} 
the imperative to maintain the questions surrounding these voices — what they sounded like, the names of those they belonged to, and so on-as questions. 


\section{Section 2:}

In the Interim: Black Noise and Manufactured Archival Silence

First published in 1997, Fred D'Aguiar's Feeding the Ghosts reads as a sharp response to the Zong archive's dearth vis-à-vis the accounts, experiences, or voices of the enslaved. The novel reconstructs the Zong case with a narrative divided into three sections and bookended by a ghostly-narrated prologue and an epilogue. The first part is set aboard the Zong. Beginning with the crew's decision to throw their captives overboard and ending three days later with their decision to stop, this narrative is told from the perspectives of the captives and crew alike. The second section narrativizes the 1783 court case between the Gregson syndicate and their insurers. The third and last section is the first person testimony of Mintah, a woman who survived the massacre and spends the rest of her life bearing witness to its victims.

Among the literary texts examined in this study, Feeding the Ghosts is the most conventional example of additive archival representation. In the novel's second section, Mintah's written account of what transpired aboard the Zong resurfaces during the insurance dispute. Although Lord Mansfield initially verifies the document-that is, he accepts that the document was written by an enslaved woman aboard the Zong, and that a woman like Mintah, literate in English, even existed at all—he is quickly convinced otherwise. First, Kelsal, the first mate, admits in his testimony that Mintah did exist, was thrown overboard, and did manage to make it back aboard the ship to incite "acts of near rebellion" among the other captives, but also casts aspersions on her credibility and impartiality as a witness (D'Aguiar 159). Kelsal testifies, "She recorded what she saw or was told from her hiding place on the ship. Whatever she wrote was dictated by her 
distress at being a slave when she had been free and could read and write" (159). After the boatswain testifies to Mintah's "insolent" and "foolish" character (161) and the second mate claims to "smell a rat" before proposing that Mintah was "not one woman but a lot of people playing the part of one woman" (162), the Gregson syndicate's lawyer capitalizes on the captain's ensuing episode of near-catatonia on the witness $s \operatorname{sand}^{6}$, then contends that "this slave's account is a fabrication by the insurers and as such it should not have been admitted as evidence because a slave could not have written it" (168). Ironically, the lawyer goes on to cite Captain Cunningham's own ledger, which he wrote aboard the ship during the massacre, to further his argument. While Kelsal succeeds in impugning Mintah's credibility by alluding to her distress over being enslaved, no onenot even the insurers' lawyer - thinks to raise similar doubts about Cunningham's ledger. In other words, the court's willingness to believe in Mintah's ostensibly obvious bias belies their inability to countenance that Cunningham may have fabricated his account of the events that transpired, which would have been in his best interest to do. ${ }^{7}$

The aforementioned irony, in fact, belies the entire section's underlying irony. The mere existence of Mintah's written testimony appeals to our desire to recover not only her voice, but the voices and subjectivities of any one of the 470 captives crammed

\footnotetext{
${ }^{6}$ Captain Cunningham's appearance at the trial was a creative liberty on D'Aguiar's part, along with the decision to change the captain's name from "Collingwood" to "Cunningham." With respect to the historical event, Captain Luke Collingwood died on 25 December 1781, three days after disembarking the Zong at Black River, Jamaica. His logbook was thought to have disappeared with him. As such, neither Collingwood or his ledger appeared during the legal proceedings two years later.

${ }^{7}$ Even though Collingwood's ledger disappeared and was therefore never accepted as evidence, the courts ultimately agreed: "The truth was, that finding they should have a bad market for their slaves, [the crew] took these means transferring of the loss from the owners to the underwriters" (qtd. in Philip 211).

Fittingly, the first chapter of Feeding the Ghosts opens with the captain exhorting the crew to throw the sick and dying Africans overboard for the express purpose of making a profit.
} 
into the Zong's cargo hold. By writing its existence into his recreation of the case, D’Aguiar satiates our desire. For Mintah's testimony is not additive archival representation. Within the context of the novel, Mintah's testimony is, in reality, archival representation, a primary source. Yet the very nature of what we most desire - the voice of the captive, the truth of her firsthand perspective on the massacre-also serves as the grounds for its dismissal as evidence. It is precisely because Mintah is an enslaved African woman that the court rejects her book as evidence. In other words, it is because Mintah is exactly the kind of heroine that many of us most want to uncover from the archive of slavery that the court finds her too incredible to be trusted or, ultimately, to have existed.

By additively offering us Mintah's written testimony only to have it rejected by his representation of the court, D'Aguiar mimes the violence of the archive itself. Yet to understand the nature of this violence, we must first understand the archive itself.

To begin with, the archive is inextricably constituted by a physical dimension of some sort. ${ }^{8}$ In "The Power of the Archive and Its Limits," Achille Mbembe describes the archive as both a "building, a symbol of public institution, which is one of the organs of a constituted state" and "a collection of documents - usually written documents - kept in this building" (Mbembe 19). According to Mbembe, every definition of the term "archives" must account for both the archive-as-building - that is, the space occupied by

\footnotetext{
${ }^{8}$ I would submit that all archives retain an inextricably spatial dimension — even with the advent of digital archives. Although digital archives host data on a website or operating system instead of housing documents in a building, this data also occupies physical space in the sense that 1) storing digital material take up memory, or space on the hard drive or server, which are themselves material objects with finite capacities for storage, and 2) these hard drives and servers take up physical space and must therefore be housed someplace themselves.
} 
the site of the building — and the archive-as-documents - the materials stored in the building. The intersection of physical space and material documents ${ }^{9}$ constitutes "the inescapable materiality of the archive" (19). By virtue of its very existence-its tangible materiality - Mbembe goes on to argue, "the archive becomes something that does away with doubt, exerting a debilitating power over such doubt. It then acquires a status of proof...that a life truly existed, that something actually happened, an account of which can be put together" (20-1). The materials stored within an archive are, essentially, preserved artifacts from the past; their irrefutable physical presence effectively imbues them with the status of empirical, positivist proof about something that happened. This status of proof in turn creates the condition of possibility for the historiographic account - taken from readings of and accounting for the archive's collections - of that time.

Yet it is precisely that it is a collection of documents housed in an archive that raises the following questions: indeed, who or what collects these documents? And by what criteria and procedures are these documents selected for acquisition, organization, and archival? "Archive," rather, is not merely a place or a collection of documents. It is not only a noun, but also a transitive verb. To archive: in the sense that someone or something must collect these documents in order to organize and store them in the archive, and in the sense that someone or something must construct the physical space in which these documents are to be stored, be it in a building or on a server. An archive, in

\footnotetext{
${ }^{9}$ With respect to the digitized archives, the documents which comprise, say, the slavery and colonial archives were themselves once material documents that were digitalized, or transcribed into a digital format. Therefore, when one views a digital representation of these archival records, the trace of the original document's materiality also imbues the digital copy with the status of proof.
} 
other words, is constructed by archiving. Mbembe describes the procedures by which the archive is constructed as "fundamentally a matter of discrimination and of selection, which, in the end, results in the granting of a privileged status to certain written documents, and the refusal of that status to others, thereby deemed "unarchivable"' (20). The matter of discrimination and of selection, of privileging certain documents as "archival" and marginalization of others as "unarchivable," is a function of power: "power to make records of certain events and ideas and not of others...power to mediate the record, power over access, power over individual rights and freedoms, over collective memory and national identity" (Schwartz and Cook 5). Is it any wonder that Mintah's testimony was rejected by the court and thereby deemed unarchivable? Indeed, according to Ann Laura Stoler, the archive is "a supreme technology of...the imperial state, a repository of codified beliefs beliefs that clustered (and bore witness to) connections between secrecy, the law, and power" (qtd. in Lowe 4). While power, Schwartz and Cook claim, does lie "at the heart... of the relationship between archives and the societies that create and use them," it is also a concept which they admit is "largely absent from the traditional archival perspective" (Schwartz and Cook 5). The implications to be derived from the intersection of archival methodology and imperial state power are staggering, especially vis-à-vis historiography. In the end, we are left with an archive that, in the words of Randolph Starn, "not more - or less - than historical, which is to say, subject to or, more exactly, products of the vagaries of circumstance, accident, and interest. This truth is one of the most obvious and paradoxical about archives" (Starn 393). In light of this, how can one claim to have constructed a representative account of what happened in the past if these accounts are based only on tangible archival material? That is, if a 
tangible primary source written by a captive like Mintah actually existed, would it have been deemed archivable? In Feeding the Ghosts, we know that it was not. Without preservation, the document may therefore have been destroyed. Even in the case where a document like Mintah's had existed, lack or denial of preservation may have destroyed its original tangibility. In either case, the existence of a document does not guarantee its preservation: continued tangibility is in most cases only possible through preservation, and preservation is only possible through the efforts of a preserver. As such, the traditional historiographer's sole reliance on tangible archival materials can be extremely dubious at best.

The situation, of course, is infinitely more complicated than I have just described. The state is not the only entity capable of archiving or preserving documents. While the British judiciary refuses to validate Mintah's testimony as archivable due to the court's antiblack racism, it is certainly possible that other entities, such as British abolitionists, may have elected to preserve the document. The fact that it never made it into the hands of such interested parties has to do with Simon, the sympathetic white crewmember to whom Mintah entrusted her book, and his decision to “keep his grip on Mintah’s book and be buried with it" (D’Aguiar 179).

Yet it is within the very space which is arealized by History's dubious reliance on the tangible that Feeding the Ghosts exists as additive archival representation. For D'Aguiar's novel is additive representation that rather performatively exposes the fallibility of the archive. In doing so, D’Aguiar makes a strong case for the necessity of additive archival representation like his own novel. In the epilogue, he brings the novel to a close with the following observations: 
There is only the fact of the Zong and its unending voyage and those deaths that cannot be undone. Where death has begun but remains unfinished because it recurs. Where there is only the record of the sea. Those spirits are fled into wood. The ghosts feed on the story of themselves. The past is laid to rest when it is told. (230).

Therein lies the aporia. The Zong's voyage is past, yet it is unending precisely because "those deaths cannot be undone." The 131 captives were murdered — are dead-yet the Zong lingers as a temporal site where "death has begun but remains unfinished because it recurs." Although the "past is laid to rest when it is told," the spirits have fled and remain at large; the ghosts continue to hunger and therefore must be fed not once and for all, but continuously. Only by telling these tales may the past be laid to rest. Yet the specters demand that witnesses tell stories about them again and again, meaning that laying the past to rest through telling, again and again and again, also lifts the past up in the very same act of telling. The specters' hunger, their need to be fed with tales of themselves, exposes their enduring relevance to our very contemporary moment — the endless task.

In the novel, Mintah commits herself to undertaking this endless task. She devotes her life after the Zong to commemorating and remembering the dead, bearing witness to them through various materially and relationally significant means such as committing her testimony to paper, carving 131 wooden figures and planting 131 coconut trees to commemorate the 131 murdered captives, and helping twice as many enslaved persons flee from Maryland to freedom in the U.S. North. "Ghosts needed to be fed," affirms the narrator. "She carved and wrote to assuage their hunger" (222). We will note that, apart from the evocation of the figured voice in Mintah's written testimony, these modes of bearing witness have little to do with voice or sound. That said, even though D'Aguiar does not foreground voice or sound as explicitly as NourbeSe does in Zong!, these 
themes nonetheless recur quite prominently in Feeding the Ghosts as both what Saidiya Hartman calls "black noise - the shrieks, the moans, the nonsense, and the opacity, which are always in excess of legibility and of the law and which hint at and embody aspirations that are wildly utopian, derelict to capitalism, and antithetical to its attendant discourse of Man" ("Venus in Two Acts" 12) and what Nancy thematizes as the interruptive voice of the other that calls us into responsibility. Black noise and the other's interruptive voice are not mutually exclusive. It would be fair to say, in fact, that they denote precisely the same ethical phenomenon.

For an utterance to be opaque to or in excess of legibility is in part constituted by but not necessarily commensurate with linguistic intransigence. In the novel, the crew communicates primarily, if not exclusively, in English. Their monolingualism does cement a language barrier between the crew and their captives, but that barrier does not inhibit other, nondiscursive forms of communication. That is, communication continues to take place not only between captors and captives, but between the captives themselves. Far from being linguistically monolithic, the captives speak in "Yoruba, Ewe, Ibo, Fanti, Ashanti, Mandingo, Fetu, Foulah” (D’Aguiar 39). The captives' linguistic and cultural diversity is indicative of the slavers' common selection process. In his book The Slave Ship: A Human History, Marcus Rediker confirms that European and American slavers were conscious that West Africa is one of the world's richest linguistic zones. Rediker goes on to cite the logs of William Simson and William Smith, who argued that "[t]he means used by those who trade to Guinea, to keep the Negros quiet, is to choose them from severall [sic] parts of ye Country, of different Languages" (qtd. in Rediker 276) and that, by taking some "of every sort aboard [the slave ship], there will be no more 
Likelihood of their succeeding in a Plot, than of finishing the Tower of Babel" (qtd. in Rediker 276). In short, it was common practice for slavers to choose Africans from different locations and cultural groups along the continent's western coast for the express purpose of preventing communication between them. All this is to say that language barriers clearly exist between many of the captives as well. This reality of the cargo hold was constructed according to the slavers' design. Yet despite this obstacle, their black noise - their screams, shrieks, moans, ululations, and so on—still signifies viscerally and primordially among them. As sonic material, their singular voices are the agents of intrusive, affective exposure to each corresponding singular captive in that cargo hold.

Black noise voices the interruption that constitutes community as being-with. A striking example of this event occurs later in the narrative, after Mintah reveals herself to the other captives who had witnessed the crew throw her into the sea. Mintah's miraculous survival leads the women to conjecture that "[t]he gods were present in her to watch over them" (D’Aguiar 93). Overjoyed, "[s]ome of the women began to clap and sing an improvised song in which they took turns to praise Mintah's name":

'Mintah is a god who walks among us as a woman.'

'Aieee!' Whistles, ululations, and rapid clapping which then slowed for the next encomium.

'A god has come as Mintah to save us from this sea.'

'Aieee!' More whistles and ululating and fast handclaps.

'The goddess Mintah will free this ship and guide it back to Africa.'

Aieees! Endless whistles, ceaseless ululations, clapping and clapping as if it were not conjecture but had come true. (93)

In its improvised call and response style, the song is equally constituted both by each singer's praises of Mintah and by the responders' whistling, ululating, and clapping. Discursive communication — as in the singers' praises — is not privileged over black 
noise — as in the responders' 'aieees!' D'Aguiar's refusal to privilege the discursive dimension of the women's voices in part evokes the multiplicity of languages spoken by the captives. Each singer's encomium is translated for us by the narrator's intermediation. Africans from different cultural groups would not have had the same assistance. For many of the women, the exact meaning of the singers' praises would have remained opaque. For these women on the other side of a language barrier, their fellows' encomiums are in excess of legibility—black noise.

In spite of, or precisely because of, this, their song nonetheless eventually "spread through the women's hold and stirred even the sick from their stupor," becoming a soundscape (94). Indeed, Rediker notes that song was "one of the recurrent sounds of the slave ship" (Rediker 282). He goes on to write, "Song was an essential means of communication among people who were not meant to communicate...: singing in African languages permitted among the captives a kind of communication that many of the European captains and crew members could not understand" (282), describing the purposes of songs such as “finding one's kind, fellow villagers, and countrymen and women....identifying which cultural groups were on board the ship" (282), "communicating important information about conditions, treatment, resistance, and events, about where the ship was going" (282-3), and, perhaps most importantly, "creating a common base of knowledge and forming a collective identity" (283). Of these, black noise relates most keenly to the last two: creating a common base of knowledge and forming a collective identity. Although each encomium's legibility would have varied between each singular person in the Zong's hold, the women nonetheless recognize that the song celebrates Mintah, a goddess they come to believe will save them 
from the sea. In other words, it is the black noise of the improvised call and response that fashions Mintah into a goddess and a savior in the women's collective imagination.

The willingness to respond varies significantly between captive and crew, however. Feeding the Ghosts opens with Captain Cunningham's exhorting the crew to accept his scheme in order to turn their loss to profit. While he makes his murderous case before the crew, both the sounds of the open sea and the captives' black noise go unacknowledged by them. Yet the narrator does acknowledge the black noise, thereby bringing it to our attentions:

More than the wind in the sails and the sea against the sides or the strain in the ship's timbers plummeting through water were the just audible cries emanating from below decks. But neither the captain nor the assembled crew seemed to hear them, or perhaps, like the sea, the ship and the sails, these cries had grown so habitual to the sailors' ears, they were no longer heard as signals of distress, but as part of the whole, all-encompassing fabric of routine. (D’Aguiar 10).

The everyday routine of the slave trade has seemingly deafened the sailors' ears. Of note in this excerpt, however, is the way in which D' Aguiar still frames their cries as "signals of distress." Rather, it is the sailors that have willfully deafened themselves to this immutable dimension of their cries. Although the other's interruptive voice gives the imperative a sonic materiality that is most proper to its exigency, its call still leaves space for refusal or non-acknowledgment.

At this point, a closer examination of the imperative is necessary. In the original French, the imperative recurs in the philosophies of Nancy and Derrida as the phrase $I l$ faut, which translates to English as It is necessary. Crucial to note is the syntax's arealization of the possibility for refusal: it is necessary, as in, it is necessary to breathe, or it is necessary to drink water. The emphasis must be placed on the event itself to 
denote its necessity. Yet despite the fact that breathing and hydrating ourselves are essential to sustaining our lives, for instance, these realities of our existences does not prohibit the possibility that we may, at any time, resolve not to breathe (as long as we remain conscious, that is) or refuse to drink water. After all, asphyxiation and dehydration are possibilities. This is the perspective from which we ought to understand the exigency of the other's voice. In other words, the other's voice is always already calling us into responsibility. We do remain free, however, to refuse to acknowledge that call in an ethical fashion. Such is the case with the crew in D'Aguiar's novel. It is not entirely that their overexposure to the captives' cries has desensitized them to their dimension as signals of distress, but rather that their sustained refusal to acknowledge them as such has congealed over time into the banality of commodification.

Yet the areality for refusal within the imperative does not neuter its exigency. When the ship suddenly shifts to starboards a short while later, the narrator observes, "Along with the creaking wood and some loose items crashing to the deck, shouts and screams climbed up the stairs leading from below and escaped through the barred hatches or else managed to squeeze through the grooves between the planks of the upper deck. A righted ship did nothing to quell them" (15). A few pages later, the narrator continues:

When the slaves heard a complaint louder than their own they listened. Their voices had become detached from them, no longer reliant on the capacity of their lungs, adding to this big engine that powered itself and understood their countless reasons for giving it expression, and grew on this understanding into an independent force so powerful now it was capable of wrecking the vessel where it was born. (26)

What is perhaps most arresting about D'Aguiar's prose in these excerpts is the agency he affords the captives' voices, which he describes in the first passage as performing actions 
in the active voice. Their shouts and screams climb, escape, and squeeze. In the second excerpt, their voices sound out together, layering into a materially affective and independent force powerful enough to destroy the Zong itself. We ought to read the narrator's description in this passage both literally and figuratively. The captives express their anger and distress sonically because it is nearly their only recourse. Shackled below decks in the cargo hold, they are forced to inhabit "a confined hole where to twist a little encumbered another, where elbows on each side speared into ribs and sleep was light, patchy, eyes wide, fitful, snatched, troubled, whimpering" (26-7). Cramped physical confinement renders other, more physical expressions of anger or distress either impossible or painful to their fellows. However, the fact remains that the captives outnumber the crew. If they were to get free and act together, they could overwhelm the crew and destroy the Zong — which nearly does occur at the close of the novel's first section. The captives' voices are therefore both literal and metonymic embodiments of their shared indignation.

Proximity and distance are crucial spatial considerations for us to consider in any phenomenology of the slave ship, but particularly this phenomenology of the Zong. In the cargo hold, the captives are constantly and intrusively forced into visceral contact with each other's bodies and effluvia. The "hot stench" of the cargo hold, in its "stale, airless confinement," is rank with "sweat from bodies that had not been allowed to wash for days," "the accident of vomit from the sick, urine from those chained for such inordinately long spells," and "faeces" (19). Although the captives' cries are only "just audible" to the crew on deck, the crew are free from the embodied immersion in the cargo hold that the captives were forced to endure. Tellingly, the crew cannot tolerate the 
atmosphere of the hold, which is "too rank for the toughest constitution among them" (19). Disgustingly, 'Kelsal saw the Africans' continued survival under such adverse circumstances as evidence of their suitability for a life of unremitting toil" (19). I would submit that the captives' forced proximity strangles the areality within the imperative for refusal while the crew's privileged distance from their captives enables their impoverished, commodifying reasoning. While the crew must occasionally enter the cargo hold to tend to their captives, the hold they have engineered ${ }^{10}$ is a material context that, not coincidentally, inhibits acknowledgment. When Kelsal descends into the cargo hold to select captives to jettison into the sea, the narrator accounts for his experience:

Howls, moans, cries, calls, and implorings in indecipherable tongues assailed Kelsal's ears. He held his lantern forward into the dreary space to pick out lame from able-bodied but could not distinguish between man and man. A sea of eyes, flesh welded into one body of complaints, on occasion separating into distinct entities of mankind, but mostly indistinguishable from another as anything but a sound, a movement, a plea inscribed on some face momentarily by a lamp, before melting back into the thick dark. (19)

Most noteworthy for our purposes is, once again, D'Aguiar's use —or, in this case, his omission of - the active voice, particularly in the phrase "a sound, a movement, a plea inscribed on some face momentarily by a lamp." From Kelsal's perspective, it is the lamp that (passively) inscribes sound, movement, or plea onto the captives' faces. Or rather, the sound, movement, and plea do not belong most properly to the captives' faces; they

\footnotetext{
10 "Engineered" not in the sense that European architects designed these slave ships, nor solely in the sense that the Zong's crew, aware as they were of the ship's material constraints, opted to kidnap 470 Africans in a space designed to hold less than half their number. Rather, "engineered" in the sense that the hold's unimaginably unsanitary condition is the direct consequence of the crew's failure to maintain proper sanitary conditions: "the fact that if at one of the day's two meals adults and children had not used the buckets allocated to them for human waste, for...just sheer lack of opportunity (before the orders and rough treatment resumed as their jailers sought to fasten them to their chains and bolts in record time so that they themselves could escape an atmosphere too rank for the toughest among them), then they were left to stew in their faeces" (D’Aguiar 19).
} 
are a property of the light issued forth by Kelsal's lamp. There is no space within his perspective to recognize the captives' singularities: each instant of singularity flashes by, briefly illumined by the lamp. By extension, it is the movement of Kelsal's arm holding the lamp that commits the inscription and subsequent erasure as the face, movement, plea, sound vanishes back into the darkness.

The crew's refusal to recognize the voices and singularities of the enslaved speaks to an ontological or relational coldness, deficiency, or impoverishment in their own subjectivities instead of a disempowerment of the captives' interruptive voices. For a crew so accustomed to commodification, a much starker encounter is required to interrupt their routine.

Fittingly, it is an encounter with a figure out of his past, Mintah, which unsettles Kelsal. When she realizes what Kelsal and the crew are doing to her fellows, Mintah feels compelled to act: "My voice has to compete with the wind as it blunts the pointed parts of the ship," she wrote, "and with the sea trying to chop the hull in two, and with the taptap-tapping of the rain testing the deck for any signs of weakness. My voice finds a way through all three. 'Kelsal'" (185)! Later, at the very moment that she makes eye contact with Kelsal, Mintah apprehends her duty. She recounts, "They come for me with a lantern that cannot burn in this bad air. They hit me in the dark and drag me out. He looks at me and I see a fire in his eyes that makes those eyes strange to me. I see he is confused by my use of his name. He is running wild. I have to stop him. How else than by calling him" (185)? By taking the form of his name to which his ears are instinctively attuned, Mintah's call disruptively forces Kelsal to acknowledge her,(25). When the encounter is played out from Kelsal's perspective, the language D'Aguiar employs to describe it 
changes drastically: "He passed his club behind him and thrust his lantern into the face of a woman to his left. She stared up at him and said accusingly, 'Kelsal!' Her eyes were wet. She bared her teeth at him. Kelsal's lantern dimmed and went out due to lack of air... Her large eyes glistened as if they retained the flame of his failed lamp" (28-9). In the active voice, the narrator writes that Mintah stared, that Mintah said Kelsal's name accusingly, that Mintah bared her teeth, that Mintah's large eyes glistened with the light. With his prose, D'Aguiar accounts for Mintah's singularity, agency, and embodiedness. However, it is crucial to note that this encounter plays out from Kelsal's impoverished perspective. It is Mintah's dogged insistence of calling his name, accusingly and reproachfully, that disrupts Kelsal's banal, commodifying gaze and forces him to respond.

The central tension between Mintah and Kelsal plays out throughout the novel, but stems from a period of time in which Kelsal, afflicted by yellow fever and marooned on the West African coastline, convalesced at the Dutch Christian mission where Mintah grew up. Immediately prior to his decision to throw her overboard for insubordination, Mintah furiously reminds Kelsal who she is, how she nursed him back to health, and the condition from which Mintah helped rescue Kelsal from:

'Kelsal!' He looks at me and grits his teeth. He comes to me. I tell him I know him from his days as a thief at the mission when he had to work for his freedom and he did not know his name and had to be told who he was time and time again. How he said it like a word that was new in the language. Not a name that belonged to him. How he had to grow to like that name again. Not having to look around expecting another person to reply when it was called. Not waiting for it to be called twice before realising it was his name and responding to it with surprise in his voice. To hear it the first time and, without a gap between the name and his thoughts because he inhabited it, be on his way. (187) 
When Mintah's written testimony surfaces in court later, her figured voice disrupts and unsettles Kelsal once again. It is at this point in the narrative that Kelsal's cruelty toward Mintah is explained from his own perspective for the first time. As he struggles to determine how he ought to account for her in his testimony, Kelsal "wasn't sure what to say. Should he tell the court that Mintah made him drink when was at the fort and delirious with fever? That she was among the young women keeping vigil over him and mopping the sweat from him during his interminable nights he woke up not knowing his name and had to be told by her, 'Kelsal. Kelsal'? That he had to repeat it to himself until it rang true" (157-8)?

Kelsal's time at the fort is characterized by his namelessness, complete dependence on the kindness of young women like Mintah, and indebtedness to the mission. "He was always free to leave," Mintah recalls in her testimony, "but not before he had repaid a little of the time everyone had devoted to him when he was ill and had to be nursed" (195). Mintah's presence aboard the Zong and the existence of her testimony at the trial two years later remind Kelsal that he is not, in fact, an immanent being or an individual, radically separate from the Africans he now makes a living enslaving and brutalizing. As such, it is this reminder that rings in Kelsal's ears whenever Mintah speaks, says his name, or reminds him of his indebtedness to her. Her status as a witness at his hour of debility—an hour he has attempted to erase from his memory by remaking himself as a competent first mate- drives him to repay her compassion with murderous violence. To Kelsal, Mintah's voice is an agent of his weakness, his shame.

Ironically, Kelsal's episode of debilitated namelessness at the mission mimes the violence of enslavement that he perpetrates upon Mintah and her fellow captives. Being 
jettisoned into the sea dissociates Mintah from her body. In D'Aguiar's prose, her

dissociation is framed as both a psychological response to trauma and a lucid and incisive reflection on the material violence of that enslavement has committed upon her body:

My body already belongs to the sea. Salt rubs itself all over it. My body belongs to the Zong. Wood presses its print wherever I lie. And the captain of the Zong. He has marked me in a ledger as his. Kelsal too thinks I belong to him. He tried to stake his claim. The crew know they can do whatever they please with it since it is theirs too before it is mine. My body belongs to everyone but me. I move in it like a thief. I do not belong to it. All this journey it is trying to separate itself from me, to be rid of me once and for all. My body seems to think that if it dies it will kill me, the intruder in it.

I am trying to get it back it back to land. I know that on land my body will recognise me again as part of it. The sea has come between my body and me. The Zong too. The captain and his crew. They have made me a stranger in my body. My name does not match my body anymore. (200)

Enslavement functions by dispossessing the captive of their bodily autonomy. A slave is kidnapped from their homeland, forced down into the cargo hold of the slave ship with their fellows, displaced across the Middle Passage, and sold into debilitating and interminable labor for the rest of their natural life. A slave is raped, impregnated, and separated from their partners and children at the masters' discretion. The psychological aftereffects of Kelsal's illness may resemble the wounds that the brutalities of enslavement have inflicted upon Mintah and her fellows, but it is a purposefully anemic resemblance at best. Whereas white brutality characterizes and defines the condition of enslavement, hospitality and the exigency of reciprocity nursed Kelsal back to health and haunt him still. As such, Kelsal is detestable for his inability to respond to Mintah's past kindness and current pleas with anything but violence, yes, but he is also pathetic in that he cannot recognize that his debility is wholly incommensurate with the violence he and the crew commit upon their captives. 
For the crew's captives, the possibility for resistance endures all the same and echoes in the voices, songs, and black noise of the captives - but the trauma of bodily dispossession carries its material consequences. As additive archival representation, Feeding the Ghosts bears witness to both. 


\section{Section 3:}

Material Responses: Voice, Song, and Pure Utterance

One of the most well-known literary-archival interventions is arguably Toni Morrison's Beloved, for which she was famously awarded the 1993 Nobel Prize in Literature. Novelistic form and situatedness in a post-Emancipation U.S. context notwithstanding, what is of interest to us about Beloved is its invocation of an extradiscursive, material soundscape. By first examining this literary soundscape in Morrison, then moving on to a reading of M. NourbeSe Philip's Zong!, our aim is to highlight

Near the close of Beloved, thirty townswomen gather outside the house of Sethe, an ex-slave woman who years earlier chose to slit her infant daughter's throat rather than allow her to be re-enslaved. Haunted by her baby girl's ghost since that day, Sethe has recently been visited by and taken in a young woman calling herself Beloved —a being who not only embodies the baby's ghost, but also the "Sixty Million and more" disremembered and unaccounted for victims of the trans-Atlantic slave trade. Sethe's recognition and claim of Beloved as her dead daughter-and Beloved's reciprocal claim of Sethe as hers-has impelled Sethe to abandon her employment to spend every waking hour both fulfilling Beloved's increasingly angry demands and attempting to explain why her murder was necessary. It is Sethe's surviving daughter Denver who ventures into the community seeking help, and it is in response to Denver's desperation that thirty townswomen gather to confront the ghost and rescue Sethe.

When the townswomen first arrive, half of them drop to their knees in prayer. The others stand "holding [the house] in a fixed glare...trying to see through the walls, behind the door, to what was really in there" (Morrison 304-5). One of these women, Ella, is 
reminded of her own experiences by Sethe's situation, imagines the "hairy white thing," implied to be the product of rape, that she "delivered, but would not nurse...coming back to whip her too," and she hollers (305). "Instantly the kneelers and the standers joined her," narrates Morrison. "They stopped praying and took a step back to the beginning. In the beginning there were no words. In the beginning was the sound, and they all knew what that sound sounded like" (305). Together, the thirty townswomen sing, shout, holler, ululate - their voices searching "for the right combination, the key, the code, the sound that broke the back of words. Building voice upon voice until they found it, and when they did it was a wave of sound wide enough to sound deep water and knock the pods off chestnut trees" (308). Together, the thirty townswomen harmonize, invoke, and recreate the primordial "sound that broke the back of words" and ultimately drives Beloved to disappear.

That phrase of Morrison's—-"sound that broke the back of words"-warrants closer attention. As Ana Luszczynska observes in The Ethics of Community: Nancy, Derrida, Morrison and Menendez, to break the back of a word is to compromise its ability to support stable discursive signification, which is a concept that the ex-slave characters are justifiably ambivalent and wary toward (Luszczynska 89). Earlier in the novel Morrison problematizes this concept of definition through an encounter between Sixo, an enslaved man, and schoolteacher, his owner. When schoolteacher accuses him of stealing a shoat, Sixo invokes the rhetoric of capital to argue that he killed, butchered, and ate the shoat to improve his own productivity as schoolteacher's slave. Ergo, by feeding — or investing in—himself, Sixo has improved schoolteacher's property the same way he "take and feed the soil, [to] give you more crop" (Morrison 224). Sixo reframes 
his theft as a utilitarian concern for the plantation's productivity and schoolteacher's economic investment. But while Sixo's argument is clever, "schoolteacher beat him anyway to show him that definitions belonged to the definer-not the defined" (225). Although Sixo is willing to rhetorically concede his personhood by referring to himself as chattel, schoolteacher retains the legal right to beat Sixo for his so-called presumption. Schoolteacher's power as "the (white) definer" of words prohibits any discursive reinterpretation by Sixo, "the (black) defined." For Morrison and Sixo, the problem with definition is that it is a function of power predicated on race. In the American English of the mid-nineteenth century, definition belongs exclusively to the white man. Crucial to note is that English's hostility to breeding possible futures for black people is a direct result of the definitional stranglehold that whites exert on language. In English, there was little room for black people to reinterpret, redefine, reinvent, or represent themselves or the world they live in. Is it any wonder, then, that Sixo ultimately "stopped speaking English because there was no future in it" (30)?

From this perspective, to break the back of a word is a liberating act. Unlike Sixo's clever argument, the thirty townswomen's sound is not discursive. That said, it is not a denial of language either. In other words, the thirty townswomen do not rhetorically subvert the capitalistic logic of slavery, nor does their sound signify a refusal to engage with the language altogether; rather, they utterly break the word's capacity to carry or convey definition. As Luszczynska notes, "The sound does not indicate an articulation of a message or idea. Although the sound breaks signifying meaning, it is, nonetheless (or consequently more), meaningful, as it can 'knock the pods off chestnut trees' and causes Sethe to "tremble like the baptized in its wash"” (Luszczynska 89). In her reading of this 
scene, Luszczynska underscores the radically interdependent, extended, and "meaninglessly meaningful" nature of the townswomen's song. Observing that the townswomen's voices are "configured as dependent on one another for the creation of this immensely powerful sound" (88) and "singing to or toward Sethe and Beloved" in such a way that "[t]hey receive neither response nor verification of the sound's reception" (89), Luszczynska obviates the sonic materiality of the singular voice. Again, this is to say that a voice is simultaneously singular — singularly of a single, unique singular being — and intrinsically toward, indelibly communicative. Before the spoken word becomes a word or speech-act, it is constituted by sound. ${ }^{11}$ As sound, a voice spaces itself out from the singular being to whom it belongs and into the surrounding environment. As such, the possibility that this voice may be heard by another capable of listening always already exists. A speaker's discursive intentionality is not necessarily clear to their listeners, nor is discursive intentionality necessarily more "meaningful" than the nondiscursive dimension, or sound. This is because voice is, primordially, sound. We cannot preempt or override its nondiscursive dimension, because this sonic materiality is what constitutes voice as voice.

The event which transpires between the thirty singing townswomen, Sethe, and Beloved turns on acknowledgment. There is the townswomen's acknowledgment that the sound is radically prior to words. There is also their acknowledgment of their interdependence, their need to sing together to find the sound. By singing to and toward Sethe and Beloved, however, the townswomen must also acknowledge them in and

\footnotetext{
${ }^{11}$ Similarly, before the written word is a word, it is constituted by inscription - the material mark made upon the surface.
} 
through rescue and confrontation. The thirty townswomen create a soundscape for and toward Sethe and Beloved that redeems the former of the latter through acknowledgment. Together, they create a soundscape - a soundscape that has the material presence to occupy the space of a "wave." As a wave, it is in part a soundscape that functions as a material acknowledgment of Beloved and the disremembered and unnamable dead she represents.

Yet theirs is a particular sort of acknowledgment. Earlier in the novel, Beloved exhorts Sethe's companion Paul D to "touch me on the inside part and call me my name," promising him, "I'll go if you call it" (Morrison 137). Despite the fact that Paul D calls her "Beloved," she does not go, implying that Beloved is not in fact her name. Indeed, Sethe never named her baby girl before or after she slit her throat. As Morrison writes in the novel's epilogue, "Everybody knew what she was called, but nobody anywhere knew her name. Disremembered and unaccounted for, she cannot be lost because no one is looking for her, and even if they were, how can they call her if they don't know her name? Although she has claim, she is not claimed" (323). The utter ineffability of Beloved's name-impossible to know because she never received one; ergo, her name does not exist — also stands metonymically for the "Sixty Million and more" whose names we can never recover, know, or speak. In this mode, acknowledgment is impossible. The living cannot bestow their names with the acknowledgment of sonic materiality; we cannot speak their names and make the air of this world shake with the vibration of each syllable. Recognizing the impossibility for what it is, the thirty townswomen acknowledge Beloved with the "meaninglessly meaningful" soundscape. And Beloved goes. 
Although Sethe and Denver are expiated of Beloved by the townswomen's soundscape and eventually forget her like a bad dream, Beloved lingers at and after the novel's close, trace-like, in non-corporeal form. Her haunting manifests in "the rustle of a skirt [which] hushes when they wake," "knuckles brushing a cheek in sleep," a shifting "photograph...looked at too long," and "her footprints [which] come and go, come and go" (324). As readers we are to understand that Sethe's obsessive devotion to her dead daughter left no room for her to create a future, that Sethe's desperate attempts to convince Beloved that her murder was both justified and necessary must have failed because Sethe's (discursive) rationale are incommensurate with the (material, nondiscursive, radically irrecuperable) acts and experiences of killing, dying, and death. From this, we are to infer that it is impossible to make the disremembered dead "go" permanently. The work of mourning is interminable.

However, Morrison's epilogue leaves space for sympathy and continued responsibility toward and for Beloved:

Down by the stream in back of 124, her footprints come and go, come and go. They are so familiar. Should a child, an adult place his feet in them, they will fit. Take them out and they disappear again as though nobody ever walked there.

By and by all trace is gone, and what is forgotten is not only the footprints but the water too and what is down there. The rest is weather. Not the breath of the disremembered and unaccounted for, but wind in the eaves, or spring ice thawing too quickly. Just weather. Certainly no clamor for a kiss.

Beloved. (324)

My reasons for beginning this section with these scenes from Beloved are that, in my view, they are singularly illustrative of the questions we have been thematizing in this study: the imperative to bear witness, the dilemmas of representation, and the sonic 
materiality of voice as acknowledgment. The climactic scene in which thirty townswomen sing together and create a soundscape for the unnamable dead is, in a very powerful sense, an antecedent for M. NourbeSe Philip's Zong!

For Zong! is premised on recognition that the "Sixty Million and more" that Beloved represents in the novel still linger in our world. These are the specters that, as we have read in the previous section on Fred D'Aguiar's Feeding the Ghosts, Mintah devotes her life to feeding, for they are hungry for stories of themselves. With Zong!, NourbeSe places her feet into Beloved's footsteps. For Zong! and the massacre its text bears witness to, these footprints - the only remaining trace - is the two-page legal text of Gregson v. Gilbert.

But it is water that bridges Morrison's and NourbeSe's texts together. When Morrison writes, "By and by all trace is gone, and what is forgotten is not only the footsteps but the water too and what is down there," she gestures toward the material remains of the enslaved who we know to have been drowned by those waters - the "Sixty Million and more" to whom Beloved (324). It is in an attempt to remember "the water and what is down there" that NourbeSe attempts to do the work of recovering, reclaiming, or exhuming those bodies from their liquid graves. The term NourbeSe uses to describe this process is exaqua: that is, to exhume the bodies of the Zong's victims from the water. In lieu of the enslaved's literal, material remains- their scoured bonesZong! orients itself toward creating a textual space where their voices may sound out. When we have observed that a voice is singular, this observation has rested on the embodiedness of our voices. As sound, our voices are constituted by the materialities of our bodies that produces them, thereby carrying something of our bodies outside of 
ourselves and spacing it out into the material world. For NourbeSe, then, Zong! as a material object is like the surface from which the sound of the captives' voices reemerge.

Zong! is a collection of found poetry, which is to say that NourbeSe constructs her poetry using only the meagre words present in the legal decision. Structurally, the poetic text of Zong! is divided into six sections: Os, Sal, Ventus, Ratio, Ferrum, and Ebora. All six of these names are Latin words; the third, however, is also a word in Afrikaans while the last is also a Yoruba word. Os translates to bones, which resonates with NourbeSe's impossible intention, apropos of Derrida in Specters of Marx, to locate the material remains of the drowned. "I want the bones," NourbeSe tells Patricia Saunders during an interview in 2008. "'Give me the bones,' I say to the silence that is so often what history presents us. And again, because that space of memory and of the archive where you come up against their inherent limitations can become a space of craziness, the bones actually ground you." (Saunders 68-9). Sal translates to salt in Latin and will in Afrikaans. Together with the following section entitled Ventus, which translates to wind, these two sections together most likely refer to the Zong's literal voyage across the Middle Passage. The fourth section's title, Ratio, translates to reason. According to Alessandro Corio in his article "Annagrams of annihilation: The (im)possible writing of the middle passage in NourbeSe Philip and Édouard Glissant," the Latin Ratio also alludes "to the legal language, where ratio decidendi indicates the central reason for a legal decision" (Corio 337). Ferrum translates to iron, evoking the balls and chains - or, literally, irons - that the captives would have been forced into after capture. In Latin, Ebora means ivory; in Yoruba, it translates to haunted. These sections comprise a sort of textual arc, but not a 
linear progression. Unlike Feeding the Ghosts or Beloved, there is no inherent narrative structuring Zong!.

The translational ambivalence which haunts the section titles—as in, "Which language should we prioritize when reading considering Sal and Ebora: Latin, Afrikaans, or Yoruba?"- speaks to an underlying multilingual potential in Zong!'s poetic text. In the "Glossary: Words and Phrases Overheard on Board the Zong," NourbeSe accounts for words from fourteen different languages other than the original English of the legal text appearing in the poetic text (Philip 183-4). These languages include, but are not necessarily limited to, Arabic, Dutch, Fon, French, Greek, Hebrew, Italian, Latin, Portuguese, Spanish, Shona, Twi, West African Patois, and Yoruba. I emphasize "not necessarily limited to" here because the poetic text, by its very fragmented nature, may potentially be read in such a way that a reader could uncover a word in another language. That is to say, a multilingual reader who is conversant in another language other than the fourteen that NourbeSe accounts for in the glossary may locate a word in a language that other readers, including NourbeSe, may not have read or written for.

Rearranging the words and letters throughout the pages of her text, NourbeSe creates fragmented poetry. These fragments, however, are not solely to be parsed for new discursive significations-although it is possible to form new, if necessarily halting, syntactical units by reading the fragments together. In "Notanda," her explanatory epilogue to the poetry, NourbeSe explains, "Zong! bears witness to the 'resurfacing of the drowned and the oppressed' and transforms the dessicated, legal report into a cacophony of voices-wails, cries, moans, and shouts that had earlier been banned from the text" (Philip 203). Later in the epilogue, NourbeSe goes on to declare, "Why the exclamation 
point after Zong!? Zong! is chant! Shout! And ululation! Zong! is moan! Mutter! Howl! And shriek! Zong! is 'pure utterance.' Zong! is Song” (206)!

Most striking about NourbeSe's arrangement of the fissured syllables is their stark juxtaposition against the blank, white page, especially in the earlier sections of the poetic text. In $O s$ and $\mathrm{Sal}$, the first two sections of the poetic text, the sparse quantity and clustered formation of words on the page makes for a sharper juxtaposition of black text on white page. In the final section Ebora, however, the poetic text is nearly unreadable. Not only have pieces of text overlapped as palimpsests, but the inscriptions themselves are fainter, almost as though the printer that produced the book had been low on ink. From the perspective of a phenomenological soundscape of the Zong, however, Ebora in particular is striking to read as either the murmurings of hungry specters or the actual drownings of the captives thrown overboard, as their voices are waterlogged. The drownings, in fact, haunt Zong!. As a simultaneously sonic and aesthetic text, Zong! is inextricably co-constituted by and exists at the intersection of these dimensions. That is to say, NourbeSe does grant the fragments a textuality as poetry, printed on the page, that is comparable to the textuality of the legal text. However, once spoken aloud, the fragments gain sonic materiality. If Zong! is wail, moan, cry, ululation, shout, shriek, howl—and, indeed, pure utterance - then it follows that the poems should be read aloud: not necessarily to uncover new meanings, but to give voice to them. The violent rearrangement NourbeSe commits upon the language, rationale, and grammar of the legal text not only mimes the violence committed upon the captives aboard the Zong by recreating a phenomenological soundscape of the slave ship, but also creates the space necessary on the page for the possibility of a voice to sound out. 
Conducive to a reading of Zong! as a sound-based recreation of the slave ship is the question of co-authorship. NourbeSe credits someone named Setaey Adamu Boateng as her coauthor. In the authors' blurb on the book's back cover, the following is written about Boateng: "Setaey Adamu Boateng is the voice of the ancestors revealing submerged stories of all who were on board the Zong" (Philip). In her acknowledgments, NourbeSe writes, "I thank the Ancestors for bestowing the responsibility of work on me. Àse" (xii). There are two crucial points we will trace: the question of co-authorship and the word àse. First, the question. If Boateng is the voice of the ancestors-possibly even including those ancestors who were thrown overboard by Zong's crew ${ }^{12}$ - then they very well could disclose the phenomenological experience on board the Zong for NourbeSe to transcribe. As such, Zong! may be read not only as additive archival representation, but testimony that counts as a primary source, archival representation. Of course, this kind of reading would necessitate a suspension of disbelief that more skeptical readers may refuse to entertain, as is their right. That said, the possibility remains for readers to explore, as we have here.

Second, the word. Àse, or àshe, is a Yoruba word. Art historian Robert Farris Thompson claims that àse literally means "'So be it,' 'May it happen"” and signifies in Yoruba culture as "divine force incarnate" (Thompson 7). According to Heather Russell:

In West African philosophy, the highest achievement of art is àshe, and

\footnotetext{
${ }^{12}$ Common sense seemingly dictates that NourbeSe's ancestors could not have numbered among the drowned precisely because she exists and is living now. Had one of her ancestors been murdered aboard Zong, then it follows that NourbeSe herself would never have been born. Apropos of that same line of thought as presented to her by an Ewe elder, however, NourbeSe writes, "A full year later, on recounting the comment to my daughter, she responds to his comment: 'Only if those who were thrown overboard left no offspring on board the Zong.' Once again I am startled. I am startled at how we, that old man and I, so easily forgot the 'meagre' ones - the children" (Philip 202). Ergo, it is entirely possible - if admittedly improbable - that one of NourbeSe's ancestors was drowned by the crew on board the Zong.
} 
when ascribed to a composition or performance, the resultant creation is contended to have all prescribed boundaries of form. As a consequence, art that achieves àshe would naturally defy conventional dictates; it would break down familiar/conventional/generic constructs, such as those governing fact, fiction, truth, reality, myth, history, nation, imagination, and narratology. It would fall 'beyond a boundary' of Eurocentric epistemology and aesthetics. The power of ashe, then, lies in its transcendent ability to cross the borders and boundaries of fixed constructs regarding knowledge, interpretation, and apprehension as well as the formal structures framing such hermeneutical engagement. (Russell 10-1)

Supposing that NourbeSe's invocation of àse signals her and Boateng's intention to create a text that transcends all conventional and Eurocentric prescription vis-à-vis form, epistemology, and aesthetics, then reading Zong! as a text that, perhaps, has achieved áse retraces the observations we have been making about the text. Indeed, as pure utterance, Zong! may also be said to inscribe pure possibility. Examples such as the aforementioned multilingual readability constitute an especially evocative example of this pure possibility. Another is the paratext of West African surnames that runs along the bottom of the pages in $O s$. NourbeSe never explains why she adds this paratext in the "Notanda," but it can be read as a litany of possibility: there is no way to say for sure if any of these names belong to the drowned and murdered aboard the Zong, but there remains a possibility that they may have belonged to some or at least one of the captives. Fittingly, it is by reading horizontally left-to-right and right-to-left, vertically top-to-bottom or bottom-to-top, or in any lateral, zig-zagging direction across the page that we may uncover new combinations of sound-pure possibility. That is to say, is it not possible that some combination of sounds read from the pages of Zong! may cohere into the name of a drowned captive, or even some of the sounds they uttered? 
Like the thirty townswomen in Beloved, Zong! in its entirety does the work of soundscape as acknowledgment: by giving it voice, we acknowledge the disremembered dead the only way we can. 


\section{Conclusion:}

\section{Living in the Afterlife of Slavery}

My thesis was written in recognition that the Zong massacre is hardly past. The lives of the 470 kidnapped Africans who were transported across or thrown overboard to drown in the waters of the Middle Passage remain relevant to our contemporary political, social, and cultural contentions with race. In other words, we have not arrived at our present moment here in the United States, with the extrajudicial murder of black people and prison industrial complex, or in the postcolonial Caribbean nations, with the Caribbean Community's (CARICOM) action plan for reparations from their former colonizers and enslavers, from out of nowhere. In "Venus in Two Acts," Saidiya Hartman observes that we live in the "afterlife of slavery" or "afterlife of property," which she describes as "the detritus of lives with which we have yet to attend, a past that has yet to be done, and the ongoing state of emergency in which black life remains in peril" ("Venus in Two Acts" 13). We have inherited a past that is constituted by the experiences of our forebearers. By writing this thesis, I intended to create a work which acknowledges the drowned and disremembered dead of the Zong and attempts to listen for the resurfacing of their voices in order to underscore both the unfinished, endless work of mourning their deaths and the intractable connection of their deaths and the endless task of mourning/listening for their disremembered voices with our contemporary moment. I believe that it is only by acknowledging the past ethically that we can recognize the methods by which to bring an end to the legacies of enslavement. In the same gesture, I want to stress that to do so ethically hinges entirely on our willingness and ability to listen to the voices of those peoples and communities most affected by the legacies of 
enslavement and to listen for, as we have spent these 50-some pages attempting, the voices of the dead.

Where this thesis concludes, we must take up another point of departure - and go further. 


\section{Bibliography}

Austen, Veronica J. “Zong!'s 'Should we?': Questioning the Ethical Representation of Trauma.” English Studies in Canada, vol. 37, no. 3-4, 2008, pp. 61-81.

Corio, Alessandro. "Anagrams of annihilation: The (im)possible writing of the middle passage in NourbeSe Philip and Édouard Glissant." International Journal of Francophone Studies, vol. 17, no. 3-4, 2014, pp. 445-68.

D’Aguiar, Fred. Feeding the Ghosts. Waveland Press, 2015.

Derrida, Jacques. Archive Fever: A Freudian Impression. University of Chicago Press, 1996.

Gilbert-Walsh, James. "Broken Imperatives: The Ethical Dimension of Nancy's Thought." Philosophy \& Social Criticism, vol. 26, no. 2, 2000, pp. 29-50.

Glissant, Édouard. Caribbean Discourse: Selected Essays. University of Virginia Press, 1989.

Hartman, Saidiya. Lose Your Mother: A Journey Along the Atlantic Slave Route. Farrar, Strauss and Giroux, 2007.

---. "Venus in Two Acts." Small Axe, vol. 12, no. 2, 2008, pp. 1-14.

Johnson, Barbara. “Translator's Introduction.” Dissemination, by Jacques Derrida, University of Chicago Press, 1981.

Lacoue-Labarthe, Phillippe, and Jean-Luc Nancy. Retreating the Political. Routledge, 2005 .

Lowe, Lisa. The Intimacies of Four Continents. Duke University Press, 2015.

Luszczynska, Ana M. The Ethics of Community: Nancy, Derrida, Morrison, and Menendez. Bloomsbury, 2011.

Mbembe, Achille. "The Power of the Archive and Its Limits." Refiguring the Archive, edited by Carolyn Hamilton, Verne Harris, Jane Taylor, Michele Pickover, Graeme Reed, and Razia Saleh, Kluwer Academic Publishers, 2002.

Morrison, Toni. Beloved. Vintage International, 2004.

Nancy, Jean-Luc. The Inoperative Community. University of Minnesota Press, 1991.

Philip, M. NourbeSe. Zong! Wesleyan University Press, 2008. 
Rediker, Marcus. The Slave Ship: A Human History. Penguin Books, 2007.

Russell, Heather. Legba's Crossing: Narratology in the African Atlantic. The University of Georgia Press, 2009.

Saunders, Patricia. "Defending the Dead, Confronting the Archive: A Conversation with M. NourbeSe Philip.” Small Axe, vol. 12, no. 2, 2008, pp. 63-79.

Schwartz, Joan M., and Terry Cook. "Archives, Records, and Power: The Making of Modern Memory.” Archival Science, vol. 2, 2002, pp. 1-19.

Starn, Randolph. "Truths in the Archives." Common Knowledge, vol. 8, no. 2, 2002, pp. 387-401.

Thompson, Robert Farris. Flash of the Spirit: African and Afro-American Art and Philosophy. Vintage Books, 1984.

Wood, David. The Step Back: Ethics and Politics after Deconstruction. SUNY Press, 2012. 